\title{
THE EFFECT OF METHIONINE ON THE UPTAKE, DISTRIBUTION, AND BINDING OF THE CONVULSANT METHIONINE SULFOXIMINE IN THE RAT
}

\author{
Robert A. Schatz, Ronald Harris, \\ and OtTo Z. SEllinger \\ Laboratory of Neurochemistry \\ Mental Health Research Institute \\ University of Michigan Medical Center \\ Ann Arbor, Michigan 48014
}

Accepted November 6, 1975

\begin{abstract}
The effect of methionine on the uptake, distribution, and binding of the convulsant methionine sulfoximine (MSO) in 7 rat brain regions, the spinal cord, the liver, and the kidney was investigated. The administration of methionine decreased the uptake of MSO in all brain regions. The uptake of MSO by and its distribution in the nervous tissue was uniform and failed to result in any preferential accumulation of the drug. Methionine decreased the amount of MSO bound to cerebral structures and to the spinal cord. MSO bound to the spinal cord was less susceptible to release by Triton X-100 than was brain-bound MSO.
\end{abstract}

\section{INTRODUCTION}

For several years, various approaches have been used in an attempt to elucidate the mechanism of action of the convulsant L-methionine- $d l$ sulfoximine (MSO). These have included studies on the effect of MSO on the cerebral metabolism of amino acids and ammonia (1-8), brain amines $(9,10)$, glycogen $(7,11)$, protein $(12-14)$, and cerebral ultrastructure $(8,15,16)$. The antagonism of MSO seizures by methionine is also well documented $(3,17,18)$. There is evidence for methionine antagonism of the effect of MSO on "bound" acetylcholine production in rat 
TABLE I

The Effect of Perfusion on Tissue RADIOACTIVITY LEVELS ${ }^{a}$

\begin{tabular}{lcc}
\hline & \multicolumn{2}{c}{$\mathrm{dpm} / \mathrm{g}$} \\
\cline { 2 - 3 } Tissue & Buffer + MSO & Buffer Only \\
\hline Brain & 36,550 & 36,866 \\
Spinal Cord & 27,150 & 26,460 \\
Liver & 179,250 & 164,969 \\
Kidney & 298,950 & 278,315 \\
\hline
\end{tabular}

${ }^{a}\left[{ }^{3} \mathrm{H}\right] \mathrm{MSO}$ was injected $3 \mathrm{hr}$ prior to sacrifice. The total radioactivity values are means obtained from 2 (buffer $+\mathrm{MSO}$ ) and 4 (buffer only) animals. For perfusion details, see Experimental Procedure.

cortical slices (19), rat brain $S$-adenosyl-L-methionine levels (20), mouse cerebellar ammonia (7), and rat brain glutamine synthetase (3). MSO and methionine have also been shown to be uptake antagonists $(21,22)$.

We have investigated the effect of methionine on the uptake, distribution and binding of $\left[{ }^{3} \mathrm{H}\right] \mathrm{MSO}$ in 7 brain regions, the spinal cord, the liver, and the kidney of the adult rat. We also attempted to establish whether methionine antagonizes MSO by disallowing MSO to reach its nervous tissue targets in sufficiently high amounts to elicit seizures.

\section{EXPERIMENTAL PROCEDURE}

Animals and Drug Treatment. Adult male Sprague-Dawley rats weighing 100-160 g were used throughout the study. A mixture of nonradioactive (Sigma Chemical Co., St. Louis, Missouri) and radioactive MSO $(0.94 \mathrm{mmol} / \mathrm{kg})$ was administered intraperitoneally alone or jointly with $\mathrm{L}$-methionine $(4.7 \mathrm{mmol} / \mathrm{kg}$ ) (ICN Biochemicals, Cleveland, Ohio) in a total volume of $10 \mathrm{ml} / \mathrm{kg}$ in saline. The animals were sacrificed 1,3 , or $6 \mathrm{hr}$ later, i.e., well before ( 1 and $3 \mathrm{hr}$ ) the onset of the seizure, or immediately preceding it $(6 \mathrm{hr}$ ).

Purification of $\left[{ }^{3} \mathrm{H}\right] M S O$. Methyl tritiated MSO $(5.1 \mathrm{mCi} / \mathrm{mmol})$, purified as previously described (23), was chromatographed on cellulose thin-layer-chromatography (TLC) plates (EM Laboratories, Elmsford, New York) in $n$-butanol, glacial acetic acid, and water (2:1:1), where it migrated identically with authentic nonradioactive MSO. Its final specific radioactivity was $3.67 \mathrm{mCi} / \mathrm{mmol}$. Solutions of $\left[{ }^{3} \mathrm{H}\right] \mathrm{MSO}$ were diluted for injection with nonradioactive MSO to achieve specific radioactivities of about $0.4 \mathrm{mCi} / \mathrm{mmol}$.

Preparation of Tissue. To minimize the contribution of circulating $\left[{ }^{3} \mathrm{H}\right] \mathrm{MSO}$ to the estimation of the tissue radioactivity, animals were perfused immediately prior to sacrifice with either ice-cold $0.1 \mathrm{M}$ sodium phosphate buffer, $\mathrm{pH} 7.4$, or buffer containing $17 \mathrm{mg} /$ liter of nonradioactive MSO. As shown in Table I, identical results were achieved, 
indicating that the presence of MSO in the perfusing medium had no effect on the measurement of the tissue stores of $\left[{ }^{3} \mathrm{H}\right] \mathrm{MSO}$. Perfusion was for $5 \mathrm{~min}$, i.e., until the perfusate was totally discolored. After perfusion, the brains were removed and dissected (24) into cerebellum (CL), brainstem (BS), striatum (ST), hypothalamus ( $\mathrm{HY}$ ), midbrain (MB), hippocampus (HI), and cerebral cortex (CX). The spinal cord, liver, and kidneys were also removed and, along with the brain regions, were weighed and homogenized in 10 vol of ice-cold $0.32 \mathrm{M}$ sucrose. The homogenates were centrifuged at $100,000 \mathrm{~g}$ for $70 \mathrm{~min}$. The resulting pellet was washed with an equal volume of sucrose and the suspension was centrifuged as above yielding the "sucrose supernatant." The washed "sucrose pellet" was homogenized in an equal volume of Triton X-100 (0.02\%) (w/v) (Sigma Chemical Co.) and was centrifuged as above yielding a "Triton supernatant" and a "Triton pellet" which was homogenized in ice-cold deionized water.

Determination of Radioactivity. Aliquots of the whole homogenate, the "sucrose supernatant," the "Triton supernatant," and of the final "Triton pellet" suspension were digested in $1 \mathrm{ml}$ of $2 \mathrm{~N} \mathrm{NaOH}$ at $65^{\circ} \mathrm{C}$ for $16 \mathrm{hr}$. Samples were neutralized with $0.2 \mathrm{ml}$ of $12 \mathrm{~N} \mathrm{HCl}$, and $10 \mathrm{ml}$ PCS (Amersham Searle, Arlington Heights, Illinois) was added for determination of radioactivity.

Protein Determination. Protein was determined by the Lowry procedure (25).

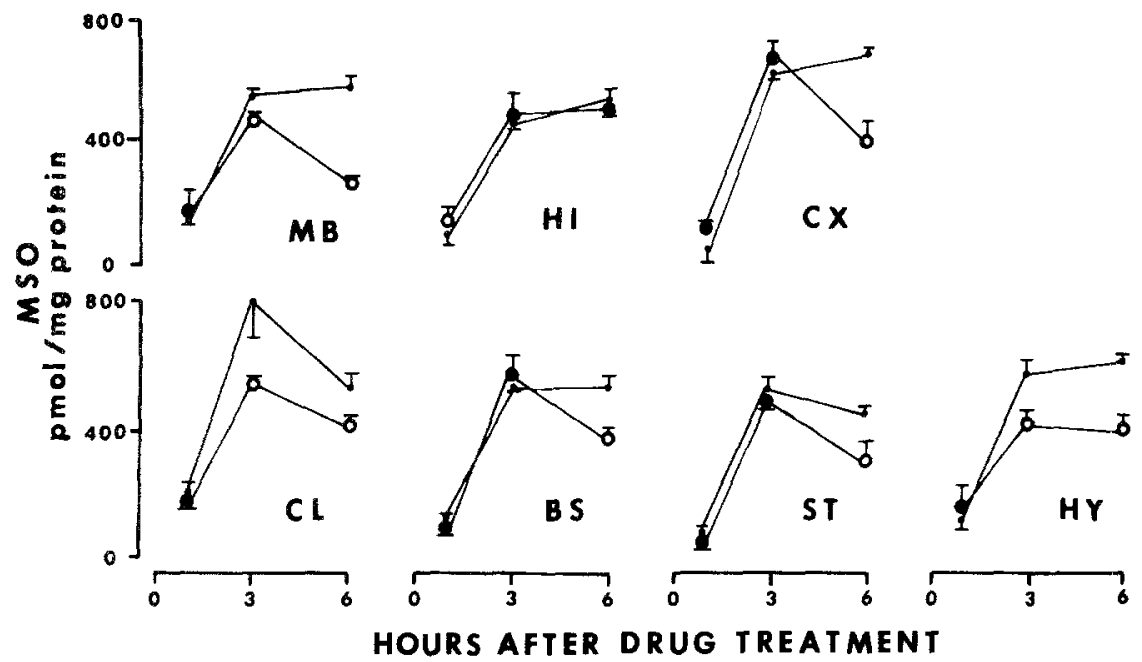

FIG. 1. The effect of methionine on the regional uptake of $\left[{ }^{3} \mathrm{H}\right] \mathrm{MSO}$ in rat brain. $\bullet \longrightarrow$ : $\left[{ }^{3} \mathrm{H}\right] \mathrm{MSO} ; \longrightarrow\left[{ }^{3} \mathrm{H}\right] \mathrm{MSO}+$ methionine. For dosages, see Experimental Procedure. Each point is the mean \pm SEM obtained from the number of animals indicated by the numeral in parentheses in $C X$, which is the same for all regions. The values represent pmoles of $\left[{ }^{3} \mathrm{H}\right] \mathrm{MSO} / \mathrm{mg}$ of protein in the regional homogenate. Open circles, $\mathrm{O}-\mathrm{O}$, denote a significant difference at the 0.05 level (see Experimental Procedure) from rats receiving only $\left[{ }^{3} \mathrm{H}\right] \mathrm{MSO}$. MB: midbrain; HI: hippocampus; CX: cortex; CL: cerebellum; BS: brainstem; ST: striatum; HY: hypothalamus. 
Statistical Analyses. Statistical comparison of MSO vs. MSO + methionine-treated groups was done using the two-tailed Student's $t$ test.

\section{RESULTS}

\section{Uptake of $\left[{ }^{3} \mathrm{H}\right] \mathrm{MSO}$ by Tissues}

There were no significant differences between MSO and MSO + methionine-treated rats in any of the brain regions at $1 \mathrm{hr}$ (Figure 1). At $3 \mathrm{hr}$, the midbrain, the cerebellum, and the hypothalamus of animals receiving MSO + methionine contained significantly less $\left[{ }^{3} \mathrm{H}\right] \mathrm{MSO}$ than was found in animals receiving MSO alone. At $6 \mathrm{hr}\left[{ }^{3} \mathrm{H}\right] \mathrm{MSO}$ levels in all brain regions, except the hippocampus, were lower than at $3 \mathrm{hr}$. The levels of $\left[{ }^{3} \mathrm{H}\right] \mathrm{MSO}$ were highest in the cerebellum at $3 \mathrm{hr}$ (about 800 $\mathrm{pmol} / \mathrm{mg}$ of protein) (Figure 1) while in all other brain regions they failed to exceed $700 \mathrm{pmol} / \mathrm{mg}$ of protein. The levels of $\left[{ }^{3} \mathrm{H}\right] \mathrm{MSO}$ were

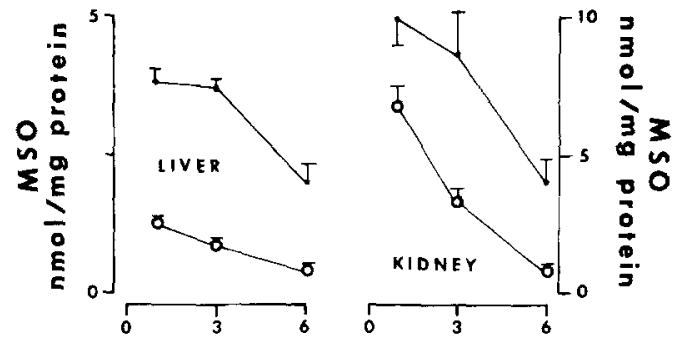

HOURS AFTER DRUG TREATMENT

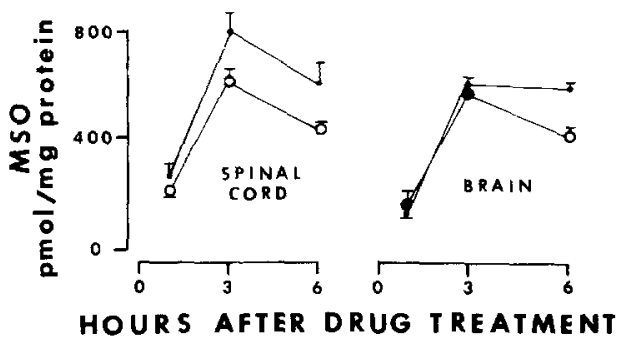

FIG. 2. The effect of methionine on the uptake of $\left[{ }^{3} \mathrm{H}\right] \mathrm{MSO}$ by whole brain, spinal cord, liver, and kidney, : [ $\left.{ }^{3} \mathrm{H}\right] \mathrm{MSO}$; $:\left[{ }^{3} \mathrm{H}\right] \mathrm{MSO}+$ methionine. For dosages, see Experimental Procedure. Each point is the mean \pm SEM obtained from the number of animals indicated by the numeral in parentheses in kidney which is the same for all organs. The values represent pmoles or nmoles of $\left[{ }^{3} \mathrm{H}\right] \mathrm{MSO} / \mathrm{mg}$ of protein in the organ homogenate. Open circles, $\mathrm{O}_{-} \mathrm{O}$, denote a significant difference at the 0.05 level (see Experimental Procedure) from rats receiving only $\left[{ }^{3} \mathrm{H}\right] \mathrm{MSO}$. 

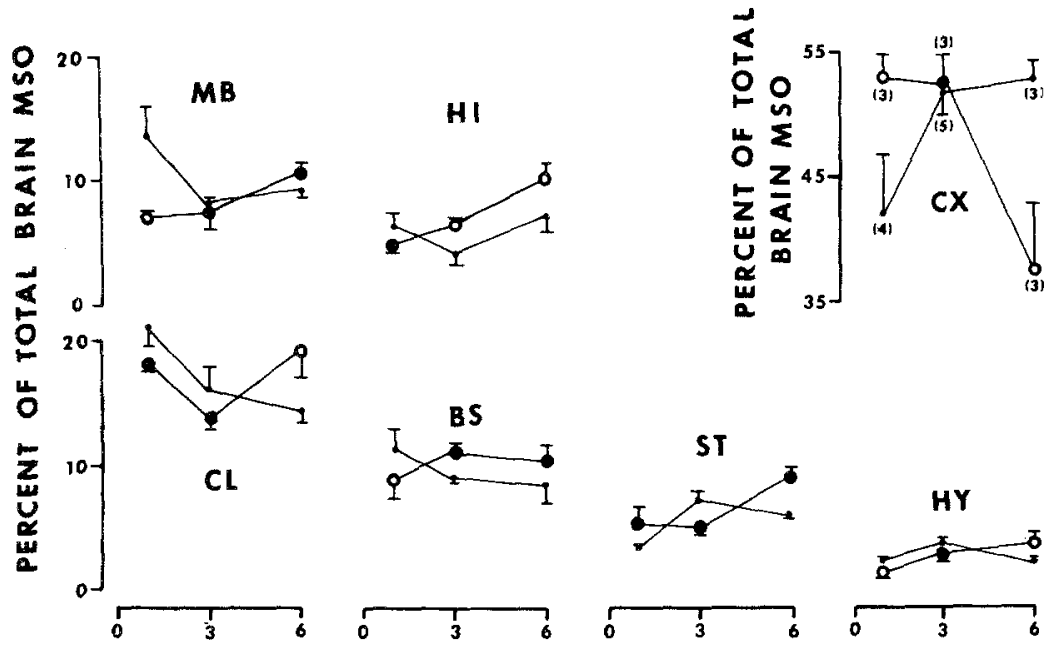

HOURS AFTER DRUG TREATMENT

FIG. 3. Effect of methionine on the regional distribution of MSO in rat brain. - $\rightarrow$ : $\left[{ }^{3} \mathrm{H}\right] \mathrm{MSO} ;-\left[{ }^{3} \mathrm{H}\right] \mathrm{MSO}+$ methionine. For dosages, see Experimental Procedure. For abbreviations, see legend to Figure 1. Each point represents the mean \pm SEM obtained from the number of animals indicated by the numeral in parentheses in $C X$, which is the same for all regions. The values refer to $\left[{ }^{3} \mathrm{H}\right] \mathrm{MSO}$ present in the region as a percent of the radioactivity in the whole brain homogenate. As in Figure 1, open circles, $\mathrm{O}-\mathrm{O}$, denote a significant difference at the 0.05 level (see Experimental Procedure) from rats receiving only $\left[{ }^{3} \mathrm{H}\right] \mathrm{MSO}$. Note difference in $\mathrm{y}$-axis scales between $\mathrm{CX}$ and all other regions.

significantly reduced by the administration of methionine, particularly in the spinal cord and the peripheral organs (Figure 2). This methionineinduced decrease became significant in the whole brain only at $6 \mathrm{hr}$ (Figure 2). The levels of $\left[{ }^{3} \mathrm{H}\right] \mathrm{MSO}$ in the spinal cord reached the cerebellar values by $3 \mathrm{hr}$ and thus exceeded those of any other brain region. During the 6 -hr experimental period the levels of $\left[{ }^{3} \mathrm{H}\right] \mathrm{MSO}$ in the peripheral organs decreased from 10 to $4 \mathrm{nmol} / \mathrm{mg}$ of protein in the kidney and from 4 to $2 \mathrm{nmol} / \mathrm{mg}$ of protein in the liver (Figure 2).

\section{Regional Distribution of $\left[{ }^{3} \mathrm{H}\right] \mathrm{MSO}$ in Rat Brain}

Only the cortex showed a sharp increase in its share of the total tissue $\left[{ }^{3} \mathrm{H}\right.$ ]MSO between 1 and $3 \mathrm{hr}$; in all other regions the $3 \mathrm{hr}$ values were not apparently different from those at $1 \mathrm{hr}$. One hour after the administration of $\left[{ }^{3} \mathrm{H}\right] \mathrm{MSO}+$ methionine, there was less $\left[{ }^{3} \mathrm{H}\right] \mathrm{MSO}$ in all brain regions, except in the cortex and the striatum, than in the corresponding regions of animals which received $\left[{ }^{3} \mathrm{H}\right] \mathrm{MSO}$ only (Figure 3). At $3 \mathrm{hr}$, 
except for the hippocampus which contained a greater share of the total $\left[{ }^{3} \mathrm{H}\right] \mathrm{MSO}$ in animals receiving $\left[{ }^{3} \mathrm{H}\right] \mathrm{MSO}+$ methionine than in those receiving $\left[{ }^{3} \mathrm{H}\right] \mathrm{MSO}$ alone, there was no significant difference in the percentages of $\left[{ }^{3} \mathrm{H}\right] \mathrm{MSO}$ between the two groups of animals. Finally, at $6 \mathrm{hr}$ a higher percentage of the total $\left[{ }^{3} \mathrm{H}\right] \mathrm{MSO}$ was found in the hippocampus, the cerebellum, and the hypothalamus of animals receiving $\left[{ }^{3} \mathrm{H}\right] \mathrm{MSO}+$ methionine than in those receiving $\left[{ }^{3} \mathrm{H}\right] \mathrm{MSO}$ only; conversely a lower percentage was found in the cortex of animals receiving $\left[{ }^{3} \mathrm{H}\right] \mathrm{MSO}+$ methionine than was present in those receiving $\left[{ }^{3} \mathrm{H}\right]$ MSO only.

\section{Effect of Methionine on $\left[{ }^{3} \mathrm{H}\right] \mathrm{MSO}$ Binding}

"Bound" $\left[{ }^{3} \mathrm{H}\right] \mathrm{MSO}$ is defined in this paper as the $\left[{ }^{3} \mathrm{H}\right] \mathrm{MSO}$ recovered in the "sucrose pellet" (see Experimental Procedure). The amount of bound $\left[{ }^{3} \mathrm{H}\right] \mathrm{MSO}$ was calculated by combining the values found in the "Triton supernatant" and the "Triton pellet" and is
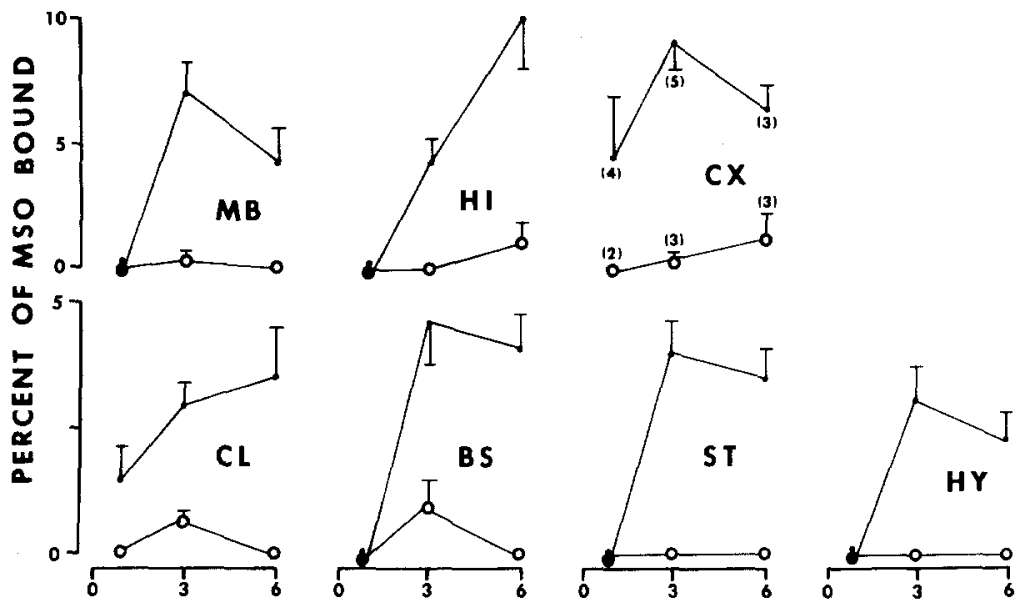

HOURS AFTER DRUG TREATMENT

Fig. 4. The effect of methionine on the regional binding of $\left[{ }^{3} \mathrm{H}\right] \mathrm{MSO}$ in rat brain.

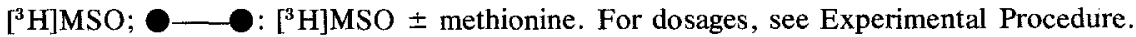

For abbreviations, see the legend to Figure 1. Each point represents the mean \pm SEM obtained from the number of animals indicated by the numeral in parentheses in CX, which is the same for all regions. The values refer to $\left[{ }^{3} \mathrm{H}\right] \mathrm{MSO}$ recovered in the washed "sucrose pellet" (see Experimental Procedure) as percent of the radioactivity present in the regional homogenate. As in Figures 1 and 3, open circles, $\mathrm{O}_{-} \mathrm{O}$, denote a significant difference at the 0.05 level (see Experimental Procedure) from rats receiving only $\left[{ }^{3} \mathrm{H}\right] \mathrm{MSO}$. 


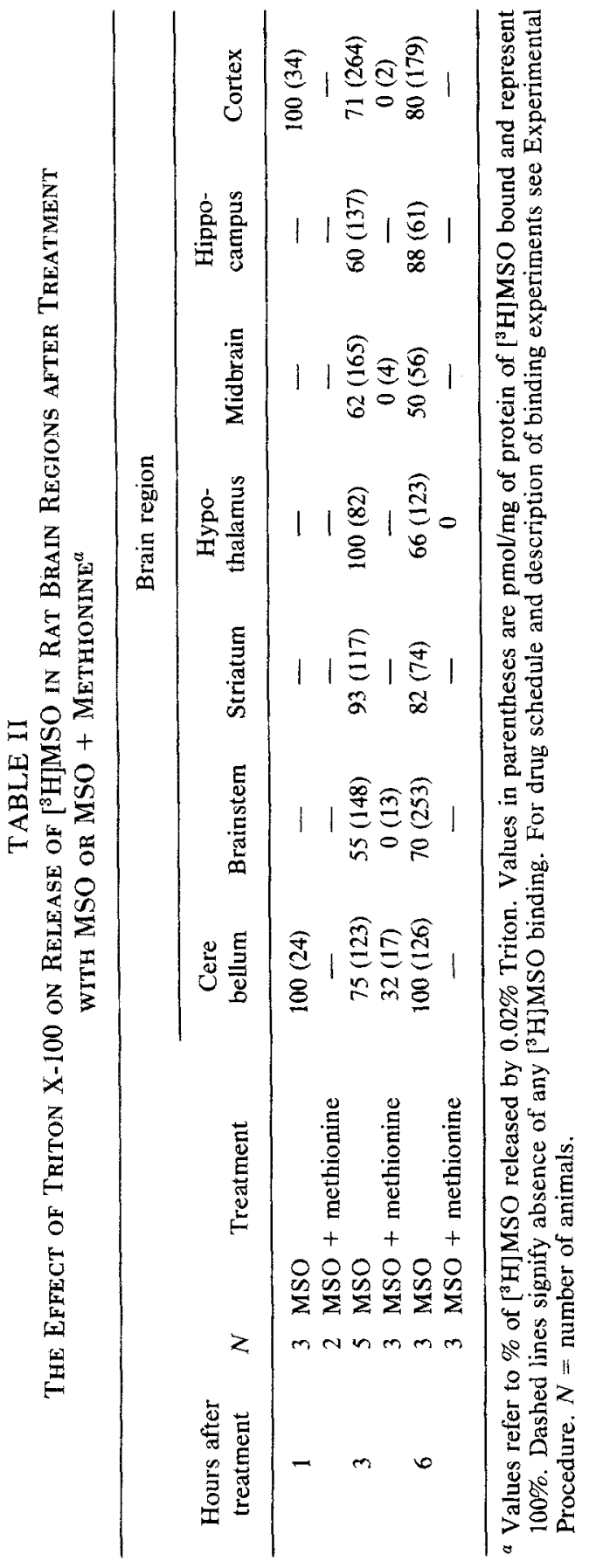


expressed as the percentage of the total $\left[{ }^{3} \mathrm{H}\right] \mathrm{MSO}$ in the tissue homogenate. At $1 \mathrm{hr}$, only the cerebellum and the cortex contained any bound $\left[{ }^{3} \mathrm{H}\right] \mathrm{MSO}$ (Figure 4). Highest values of bound $\left[{ }^{3} \mathrm{H}\right] \mathrm{MSO}$ were found in the hippocampus at $6 \mathrm{hr}$ and in the cortex at $3 \mathrm{hr}$ (about 9\%). A notable finding, shown in Figure 4 as well as in Table II, was that methionine greatly reduced the binding of $\left[{ }^{3} \mathrm{H}\right] \mathrm{MSO}$ in all brain regions. This finding could be confirmed when bound $\left[{ }^{3} \mathrm{H}\right] \mathrm{MSO}$ determinations were performed on samples of whole brain (data not shown).

\section{Effect of Triton X-100 on MSO Release}

Triton X-100 homogenization (see Experimental Procedure) released all of the bound $\left[{ }^{3} \mathrm{H}\right] \mathrm{MSO}$ (Table II) at $1 \mathrm{hr}$, while at 3 and $6 \mathrm{hr}$ this treatment proved effective only in releasing $\left[{ }^{3} \mathrm{H}\right] \mathrm{MSO}$ bound in the absence of methionine. The small amounts of $\left[{ }^{3} \mathrm{H}\right] \mathrm{MSO}$ bound when methionine was coadministered (Figure 4) became resistant to Triton except in the cerebellum, where $32 \%$ of the tissue-bound $\left[{ }^{3} \mathrm{H}\right] \mathrm{MSO}$ was released. Triton X-100 also effectively released $\left[{ }^{3} \mathrm{H}\right] \mathrm{MSO}$ bound in the peripheral organs, although this process appeared to diminish in intensity with time (Table III).

\section{DISCUSSION}

The concurrent administration of $\left[{ }^{3} \mathrm{H}\right] \mathrm{MSO}+$ methionine resulted, within 3-6 hr, in general and significant reductions of $\left[{ }^{3} \mathrm{H}\right] \mathrm{MSO}$ uptake by all brain regions except the hippocampus (Figure 1). This finding extends our previous observation (22) which dealt with the cortex and the cerebellum only, to 5 additional brain regions. Furthermore, as shown in Figure 2, significantly less $\left[{ }^{3} \mathrm{H}\right] \mathrm{MSO}$ was present in the spinal cord, the liver, and the kidney of animals receiving the combination of $\left[{ }^{3} \mathrm{H}\right] \mathrm{MSO}+$ methionine than in those receiving only $\left[{ }^{3} \mathrm{H}\right] \mathrm{MSO}$. This protective effect of methionine became apparent as early as $1 \mathrm{hr}$ postadministration and lasted throughout the entire preconvulsant period.

The accumulation of $\left[{ }^{3} \mathrm{H}\right] \mathrm{MSO}$ in the brain regions (Figure 3) was, in general, directly proportional to their weights. There was, however, a shift in the regional partition of $\left[{ }^{3} \mathrm{H}\right] \mathrm{MSO}$ with time, as evidenced by its marked increase, between 1 and $3 \mathrm{hr}$, in the cortex and its parallel decrease in the cerebellum, the midbrain, the brainstem, and the hippocampus. It is of particular interest that the administration of methionine altered the time course of the regional partition of $\left[{ }^{3} \mathrm{H}\right] \mathrm{MSO}$ 
TABLE III

The Effect of Triton X-100 on Release of [ $\left.{ }^{3} \mathrm{H}\right] \mathrm{MSO}$ in Rat Organs after TREATMENT WITH MSO OR MSO + METHIONINE ${ }^{a}$

\begin{tabular}{|c|c|c|c|c|c|c|}
\hline \multirow{2}{*}{$\begin{array}{l}\text { Hours after } \\
\text { treatment }\end{array}$} & \multirow[b]{2}{*}{$N$} & \multirow[b]{2}{*}{ Treatment } & \multicolumn{4}{|c|}{ Rat organ } \\
\hline & & & Brain & Spinal cord & Liver & Kidney \\
\hline \multirow[t]{2}{*}{1} & 3 & MSO & $100(8)$ & $100(227)$ & $100(579)$ & 96 (669) \\
\hline & 2 & $\begin{array}{l}\mathrm{MSO}+ \\
\text { methionine }\end{array}$ & - & $100(27)$ & 78 (122) & $100(688)$ \\
\hline \multirow[t]{2}{*}{3} & 5 & MSO & 79 (148) & $100(105)$ & 71 (158) & $94(720)$ \\
\hline & 3 & $\begin{array}{l}\mathrm{MSO}+ \\
\text { methionine }\end{array}$ & $14(4)$ & - & $0 \quad(37)$ & $87(320)$ \\
\hline \multirow[t]{2}{*}{6} & 3 & MSO & $8190)$ & $44(63)$ & $40 \quad(102)$ & $39(369)$ \\
\hline & & $\begin{array}{l}\mathrm{MSO}+ \\
\text { methionine }\end{array}$ & $0(2)$ & - & $60(35)$ & $0(15)$ \\
\hline
\end{tabular}

${ }^{a}$ Values refer to $\%$ of $\left[{ }^{3} \mathrm{H}\right] \mathrm{MSO}$ released by $0.02 \%$ Triton. Values in parentheses are $\mathrm{pmol} / \mathrm{mg}$ of protein of $\left[{ }^{3} \mathrm{H}\right]$ MSO bound and represent $100 \%$. Dashed lines signify absence of any $\left[{ }^{3} \mathrm{H}\right] \mathrm{MSO}$ binding. For drug schedule and description of binding experiments see Experimental Procedure. $N=$ number of animals.

for, under these conditions, the drug reached high cortical levels at $1 \mathrm{hr}$, but, by $3 \mathrm{hr}$, appeared to decay and accumulate instead in the cerebellum and the hippocampus.

Although quantitatively much inferior, the binding of $\left[{ }^{3} \mathrm{H}\right] \mathrm{MSO}$ in brain appeared tighter when the drug was given with methionine (Tables II and III), rather than alone, a phenomenon briefly noted before (22). An increase in Triton-resistant $\left[{ }^{3} \mathrm{H}\right] \mathrm{MSO}$ binding in the peripheral organs with time was also noted, and this occurred after administering $\left[{ }^{3} \mathrm{H}\right] \mathrm{MSO}$ by itself and with methionine (Table III). $\left[{ }^{35} \mathrm{~S}\right] \mathrm{MSO}$ binding in mouse brain and liver was previously reported by Rao and Meister (26) who identified the presumably protein-bound radioactivity as MSO phosphate. We have heretofore failed to demonstrate soluble MSO metabolites in rat brain $(22,25)$. Moreover, more recently we conducted a number of chromatographic experiments using a variety of organ extracts of $\left[{ }^{3} \mathrm{H}\right] \mathrm{MSO}$-treated rats and uncovered no evidence for the existence of soluble $\left[{ }^{3} \mathrm{H}\right] \mathrm{MSO}$ metabolites.

\section{ACKNOWLEDGMENT}

This work was supported by the USPHS (grants MH 07417 and NS 06294) and a grant from the Epilepsy Foundation of America. 


\section{REFERENCES}

1. Peters, E.L., and Tower, D.B. 1959. Glutamic acid and glutamine metabolism in cerebral cortex after seizures induced by methionine sulfoximine. J. Neurochem. 5:8090.

2. VAN den Berg, C.J., and VAN Den Velden, J. 1970. The effect of methionine sulfoximine on the incorporation of labelled glucose, acetate, phenylalanine and proline into glutamate and related amino acids in the brains of mice. J. Neurochem. 17:985-991.

3. Sellinger, O.Z., Azcurra, J.M., and Ohlsson, W.G. 1968. Methionine sulfoximine seizures VIII. The dissociation of the convulsant and glutamine synthetase inhibitory effects. J. Pharmacol. Exp. Ther. 164:212-222.

4. Tews, J.K., and Stone, W.E. 1964. Effects of methionine sulfoximine on levels of free amino acids and related substances in brain. Biochem. Pharmacol. 13:543-545.

5. Ghittoni, N.E., and Sellinger, O.Z. 1970. Cerebral methionine and cysteine levels in rats after injection of the convulsant methionine sulfoximine. Pharmacol. Res. Commun. 2:117-120.

6. Stransky, Z. 1969. Time course of rat brain GABA levels following methionine sulfoximine treatment. Nature (London) 224:612-613.

7. Folbergrova, J., Passonneau, J.V., Lowry, O.H., and Schulz, D.W. 1969. Glycogen, ammonia and related metabolites in the brain during seizures evoked by methionine sulfoximine. J. Neurochem. 16:191-203.

8. Hindfelt, B., and Plum, F. 1975. L-methionine DL-sulfoximine and acute ammonia toxicity. J. Pharm. Pharmacol. 27:456-458.

9. DeRobertis, E., Sellinger, O.Z., Rodriguez de Lores Arnaiz, G., Alberici, M., and ZIEHER, L.M. 1967. Nerve endings in the methionine sulphoximine convulsant rats, a neurochemical and ultrastructural study. J. Neurochem. 14:81-89.

10. Schatz, R.A., and Sellinger, O.Z. 1975. The elevation of cerebral histamine- $N$ and catechol- $O$-methyl transferase activities by $\mathrm{L}$-methionine- $d l$-sulfoximine. J. Neurochem. 25:73-78.

11. Phelps, C.H. 1975. An ultrastructural study of methionine sulphoximine-induced glycogen accumulation in astrocytes of the mouse cerebral cortex. J. Neurocytol. 4:479-490.

12. Sellinger, O.Z., Azcurra, J.M., Ohlsson, W.G., Kohl, H.H., and Zand, R. 1972. Neurochemical correlates of drug-induced seizures: Selective inhibition of cerebral protein synthesis by methionine sulfoximine. Fed. Proc. 31:160-165.

13. Folbergrova, J. 1962. Effect of D,L-methionine sulfoximine on incorporation of $\left[{ }^{35} \mathrm{~S}\right]-$ methionine into proteins of brain cortex slices. Nature 194:871-873.

14. Lisy, V., and LodiN, Z. 1975. The influence of L-methionine-D,L-sulfoximine on the labelling of acid soluble fraction and proteins of the brain cortex after intraperitoneal injection of ${ }^{14} \mathrm{C}$-leucine. Exp. Pathol. (Jena) 10:211-215.

15. Rizzuto, N., and Gonatas, N.K. 1974. Ultrastructural study of the effect of methionine sulfoximine on developing and adult rat cerebral cortex. J. Neuropathol. Exp. Neurol. 33:237-251.

16. Gutierrez, J.A., and NorenberG, M.D. 1975. Alzheimer II astrocytosis following methionine sulfoximine. Arch. Neurol. 32:123-126.

17. Reiner, L., Misani, F., and Weiss, P. 1950. Studies on nitrogen trichloride treated prolamines. VI. Suppression of the development of convulsions with methionine. Arch. Biochem. 25:447-454. 
18. Lodin, Z., and KolouseK, J. 1958. The effect of some amino acids on the neurotoxic action of methionine sulfoximine. Physiol. Bohemosl. 7:87-94.

19. Tower, D.B., and EllrotT, K.A.C. 1953. Experimental production and control of an abnormality in acetylcholine metabolism present in epileptogenic cortex. J. Appl. Physiol. 5:375-391.

20. Schatz, R.A., and Sellinger, O.Z. 1975. Effect of methionine and methionine sulfoximine on rat brain $S$-adenosyl methionine levels. J. Neurochem. 24:63-66.

21. RoTH, J.S., WASE, A., and REINER, L. 1952. The distribution of $\mathrm{S}^{35}$-labeled Lmethionine sulfoximine in the rat. Science 115:236-238.

22. Ghittoni, N.E., Ohlsson, W.G., and Sellinger, O.Z. 1970. The effect of methionine on the regional and intracellular disposition of $\left[{ }^{3} \mathrm{H}\right]$-methionine sulfoximine in rat brain. J. Neurochem. 17:1057-1068.

23. BRINK, J.J., and SELLINGER, O.Z. 1967. A rapid, preparative separation of methionine sulfoximine from methionine sulfoxide. J. Chromatog. 27:269-270.

24. Glowinski, J., and IVERSEN, L.L. 1966. Regional studies of catecholamines in the rat brain. I. The disposition of $\mathrm{H}^{3}$ norepinephrine, $\mathrm{H}^{3}$ dopamine and $\mathrm{H}^{3}$ dopa in various regions of the brain. J. Neurochem. 13:655-669.

25. Lowry, O.H., Rosebrough, N.J., Farr, A.L., and Randall, R.J. 1951. Protein measurement with Folin phenol reagent. J. Biol. Chem. 193:265-275.

26. RAO, S.L.N., and Meister, A. 1972. In vivo formation of methionine sulfoximine phosphate, a protein-bound metabolite of methionine sulfoximine. Biochem. 11:11231127.

27. Lamar, C., Jr., and Sellinger, O.Z. 1965. The inhibition in vivo of cerebral glutamine synthetase and glutamine transferase by the convulsant methionine sulfoximine. Biochem. Pharmacol. 14:489-506. 